\title{
Discoursing development: \\ the case of the European Investment Bank
}

Ivan Lesay

Institute of Economic Research, Slovak Academy of Sciences, Slovakia

\begin{abstract}
Key words
European Investment Bank, economic development, development discourse, development economics theories, Critical Discourse Analysis.
\end{abstract}

JEL classification F02, O19

\section{Palauras-chave}

Banco Europeu de Investimento, desenvolvimento econômico, discurso de desenvolvimento, teorias do desenvolvimento econômico, Análise Crítica do Discurso.

Classificação JEL F02, O19

\section{Abstract}

The European Investment Bank (EIB) has recently become a relevant development player; nevertheless, its theoretical competence to operate in developing countries has not been scrutinised. This paper aims, first, to reconstruct the development argument of EIB, i.e., to map how EIB claims its investments contribute to the economic development of developing countries. Second, we confront the reconstructed Bank's development discourse with development economics theories in an effort to identify its theoretical inspirations. Third, we apply Critical Discourse Analysis to identify EIB's discursive practices. The paper argues that EIB's development discourse is inspired predominantly by the Washington Consensus, that it is minimalist and underdeveloped, and that it uses discursive techniques to promote and perpetuate EIB's hegemonic and ideological positions. We conclude that, from a development economics perspective, EIB is theoretically limited and unqualified.

\section{Resumo}

O Banco Europeu de Investimento (BEI), embora tenha se tornado um importante agente do desenvolvimento, náo teve sua competência para opevar em paises em desenvolvimento devidamente analisada e comprovada. Este artigo procura, em primeiro lugar, reconstruir o argumento sobre como seus investimentos contribuem para os paises em desenvolvimento. Em segundo lugar, confronta-se este discurso com as teorias do desenvolvimento econômico, de forma a identificar suas inspiraçóes teóricas. Em seguida, utiliza-se a Análise Crítica do Discurso para avaliar tais práticas discursivas. Argumenta-se no artigo que o discurso de desenvolvimento do BEI é predominantemente inspirado pelo Consenso de Washington, que é minimalista e pouco desenvolvido, bem como emprega técnicas discursivas que promovem e perpetuam as posiçóes hegemônicas e ideológicas do Banco. O artigo conclui que, da perspectiva da economia do desenvolvimento, o BEI é limitado e desqualificado. 


\section{Introduction}

Despite the growing significance of the EIB development mandate, the economico-politico-ideological sources of this institution have not been mapped out so far. The aim of this paper is to identify which current of development economics thinking inspires EIB investment outside the European Union and what discoursive practices are used to justify these investments. The major question that this paper examines is thus whether it is possible to identify and reconstruct EIB's development argument, and whether it can be claimed to overlap with one or more development economics traditions? Besides ideological sources, the paper also seeks to investigate discoursive techniques applied by EIB in its development discourse.

International financial institutions (IFIs) operating in developing countries, notably the World Bank and International Monetary Fund (IMF), have been under critique for the impact of their activities since the 1980s.

Although EIB started operating in Africa already in the 1960s, it gets under scrutiny only in the last few years, and still only by a few NGOs. When reading texts related to development published by EIB, one can be surprised how smoothly and non-problematically the issue of development is presented. An optimistic vision is being put forward of how the EIB shareholders' interests somehow automatically accord with the needs of developing countries. Even at the time when the World Bank already uses a relatively sophisticated language (incorporating also some of the previous criticisms against the limited approach to developing countries) when justifying its development activities, EIB seems to content itself with a minimum of simple phrases to substantiate its 'development investments' outside the EU. It is therefore worthwhile to analyse to what extent EIB is actually theoretically fit and competent to engage in the issue of development and where it draws its inspiration from.

There are several reasons to study EIB in the context of development economics. First, EIB's activity in developing countries has been increasing in volume and in significance in the last two decades and is expected to continue in this trend. Second, as already indicated, the Bank's operation outside the EU has not been completely uncontroversial - with its increasing activity in developing countries, also its impact started to be challenged 
${ }^{1}$ See Colajacamo (2006), WEED (2008), Pottinger (2007), Wright (2007),

Kumwamba and Simpere (2008) and Wilks (2010).

${ }^{2}$ See Cox (1996), Bøås and McNeill (2004) and Ngugi (2006). and its development record disputed by local communities and nongovernmental organisations. ${ }^{1}$ Third, the two abovementioned phenomena have not been paid an appropriate attention in academia and are underresearched - no academic publication deals with the link between EIB and development. Fourth, documenting potential deficiencies of the Bank in this area of its activity can contribute to critical questioning and potentially changing the power relations EIB is part of. Similar research tasks have been undertaken regarding other IFIs. Notably the World Bank and IMF have been charged with representing their shareholders' interests in the first place, and with creating and shaping the global development discourse ideologically, i.e. with the aim to attain these geopolitical interests. ${ }^{2}$ The paper thus also aims to check how similar claims would be tested against EIB and whether EIB does its part in perpetuating the hegemonic development discourse as practised by other IFIs.

The study is structured into two major parts. After the introduction, EIB is introduced including its development mandates. The same section also presents four traditions in development economics - early development economics, the Washington Consensus, the postWashington Consensus, and heterodox development economics. The core section of the paper analyses the theoretical background and discoursive practices of EIB's development related texts.

\section{2_The European Investment Bank and development economics}

The EIB was created in 1958 under Treaty Establishing the European Economic Community to provide longterm finance mainly for infrastructural integration of what later became the European Union. EIB has become one of the largest IFIs in the world. With an annual portfolio of EUR 57.6 billion for 2008, EIB is responsible for about double the amount of financial investments made by the World Bank. EIB is a non-profit, EU policy-driven public bank which invests in projects that further EU policy objectives. EIB is primarily an investment bank and, unlike the World Bank and other IFIs, it does not invest in programmes of structural reforms and transformations. EIB has a dual identity as a European institution and a bank. While operating 
within the EU framework, the Bank is financially autonomous with a capital of EUR 232 billion, subscribed by the EU Member States, which are the EIB's shareholders. The 27 Member States of the EU jointly provide the EIB's capital, their respective contributions reflecting their economic weight within the Union. Only $5 \%$ of the capital is paid in. EIB is a self-financing organisation which raises the bulk of its lending resources on the international capital markets where long-term funds can be raised through bonds and other types of security. The Bank does not engage in over-the-counter, private customer accounts or foreign exchange business.

EIB's investment portfolio, mission and area of interest has been developing and grown substantially since its creation, and now EIB already is a major financier of development projects around the world, with EUR 6.15 billion or more than $10 \%$ of its overall lending portfolio lent outside of the EU in 2008. According to some statistics, EIB is the biggest public financier not only in the world, but also in developing countries (Wright 2007: 55). ${ }^{3}$ The globally expanding activities are the result of political decisions by the Council of the EU to extend mandates originally given to EIB. The first global 'development mandate' was given to EIB by the Council in 1997 (Council Decision 97/256/ $E C$ ). EIB has adopted to identify itself also as EU's 'development bank' recently. ${ }^{4}$ However, despite some level of expertise, and despite its clear development role and impacts, EIB (if compared e.g. with the World Bank) has not elaborated any genuine research or analysis on the issue of development. In the region of Africa, Caribbean, Pacific (ACP), EIB lends under the framework of the EUACP cooperation legislative documents (previously Yaoundé and Lomé Conventions, now Cotonou Agreement), focusing on infrastructure, energy, financial sector and small and medium enterprises, industry, and services. Lending of EIB in the Asian and Latin American countries (ALA) is governed by the mandates from the Council

${ }^{3}$ This statistics does not take
the World Bank Group as one
institution. Instead, it is split
into its individual financial
institutions - IBRD, IFC, IDA
${ }^{4}$ In EIB Group's 2005
Annual Report (pp. $6-7$ )
for example, EIB's president
Philippe Maystadt stated
that the Bank's mandates
outside of the EU “are no
longer restricted to simply
financing but have become
genuine 'development
mandates' involving the use of a strategic approach, financial instruments and conditionality different from those applied in the EU" and added that the renewed EIB's external mandates for the period 2007-2013 will "most probably, confirm the EIB's role as a 'development bank' in regions with which the EU has chosen to maintain a preferential partnership" [quotation marks in original]. 
of the EU. Previously formulated as financing projects of 'mutual interest' in the region, EIB's recent objectives in ALA are to contribute to environmental sustainability (including climate change mitigation), to the energy security of the EU, and continue to support EU Member States' FDI projects.

The first important and relevant document analysed in the paper is
Development Impact Assessment Framework of Investment Facility Projects (DIAF).

Another noteworthy document, or rather a set of documents, is Economic Report on Partner Countries published annually since 2005 by EIB's Development Economics Advisory Service (DEAS). Other EIB documents referring to the issue of development are also analysed, namely EIB Group's Annual Reports, Investment

\section{Chart 1: Hierarchy and relations of ElB development-related texts}

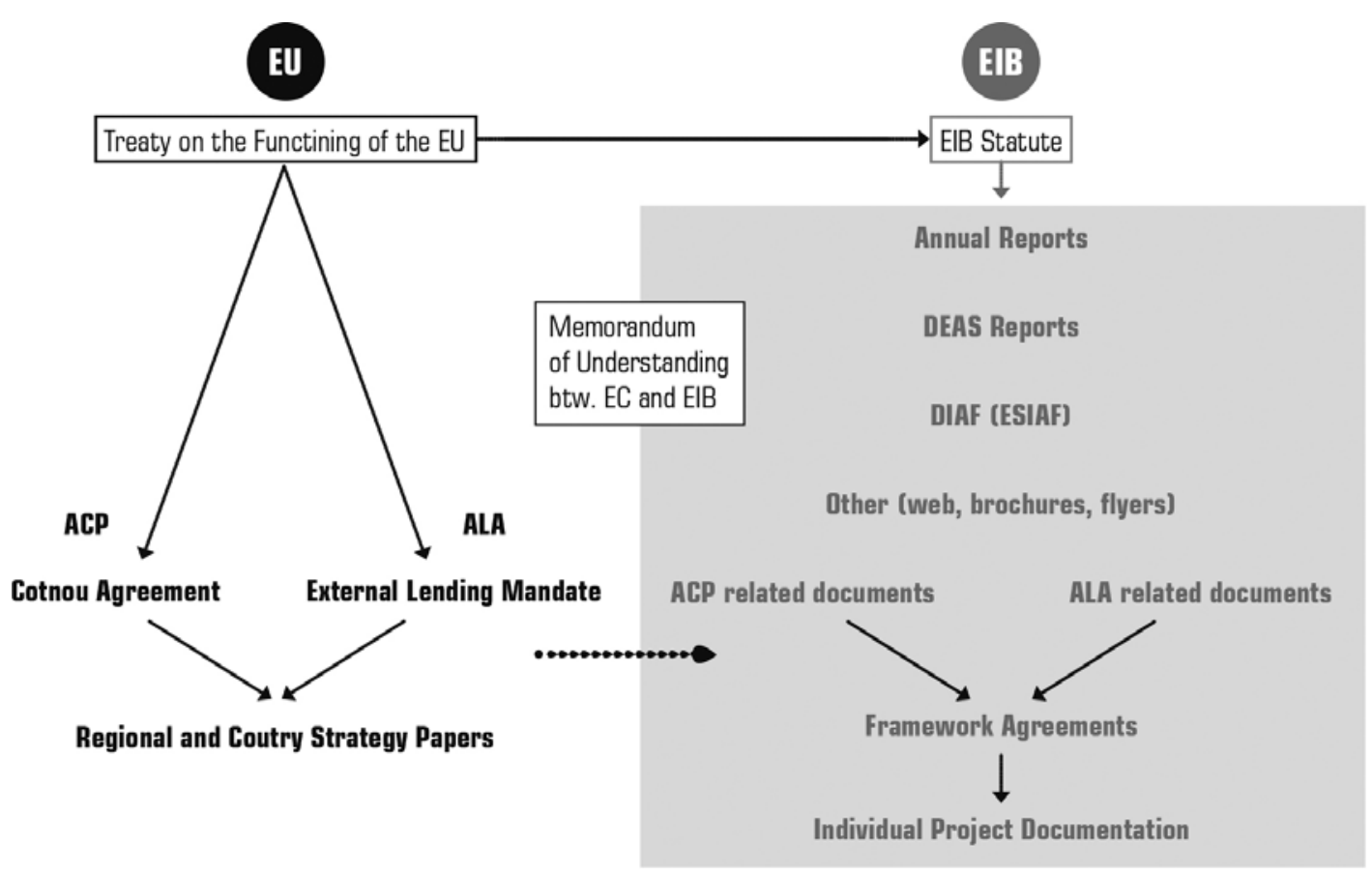


Facility - Annual Reports, various regional and sectoral EIB brochures, flyers, and webtexts, and individual project level documentation related to the selected cases. For the relation among the EIB documents, and between the EIB documents and relevant EU documents, see Chart 1. ${ }^{5}$

Development economics is a very diverse social science discipline. Many currents, traditions, schools, and theories can be identified within it. For the purposes of this paper, development economics - as a separate subdiscipline of economics established and institutionalised after World War II - is divided into four more or less coherent currents:

1_Early development economics

2_Washington Consensus

3_Post-Washington Consensus

4_Heterodox development economics

It is an arbitrary categorisation and is in no way intended to provide an exhausting review of the discipline or to draw sharp lines between the currents. Far from insisting that it is the only valid one, the division rather serves the purpose of presenting a variety of theoretical approaches - both within and outside the development economics mainstream, both in the post-war history and in the present - where EIB could possibly draw its inspiration from. As EIB is conceived as an institution fostering economic development in this paper, the four currents constitute a sufficient reference point for its development discourse.

The section below outlines the key features of the four development economics currents - early development economics, the Washington Consensus, the post-Washington Consensus, and heterodox development economics. The early development economists ${ }^{6}$ were not a homogenous group of thinkers; however, there are common denominators for their major can often be in conflict with development goals in the long run, it is always important to ask which 'policy coherence' is EIB implementing in its 'global mandate' (Tricarico 2008). I argue that EIB applies a 'selective policy coherence', i.e. it refers only to those (parts of) EU documents that fit to its conception of development.

${ }^{6}$ See Rosenstein-Rodan (1943), Nurkse (1961), Hirschman (1958), Rostow (1960), Gerschenkron (1962), Prebisch (1948), Singer (1950), Lewis (1954). 
arguments. They all called for an intended and massive industrialisation it was supposed to improve developing countries' terms of trade, alleviate their balance of payment problems, contribute to economic growth and poverty reduction, and modernise societies. Despite the recognition that the private sector fulfils an important function in development, too, it was definitely the state to assume the leading developmental role and an activating role in industrialisation. Regarding the role of international relations and trade, there was a strong tradition within this current of development economics that stressed structural differences between developed and developing economies, as well as asymmetrical international relations between the two groups. Furthermore, flows of investment and credit from more developed to

\footnotetext{
${ }^{7}$ See for example Singer (1950:

484 -485), or Lewis (1954: 27).

${ }^{8}$ See in Williamson (1990),

Krueger (1997), Bhagwati and

Srinivasan (2002), Bauer (1972 and 1984), and Lal (2006).

${ }^{9}$ See for example Krueger (1974), or Berg (1981).

\author{
10 The urge for a massive \\ privatisation was pronounced \\ particularly since 1990s. \\ Influential pro-privatisation \\ reports published and \\ promoted by the World Bank \\ include for example Shirley \\ and Nellis (1991) and Galal \\ et al. (1994).
}

developing economies were seen as important and with a potential to be beneficial for the development of the latter group. However, the first critiques and reservations were formulated already in this period, especially by the structuralist economists. ${ }^{7}$

The Washington Consensus development economics does not call for a structural change, and if it discusses development, then mainly in terms of increasing per capita income and productivity. The Keynesian recipes of inward-marketoriented import substitution are no more discussed; instead, export-led growth models inspired by neoclassical economics gain in dominance. The Washington Consensus maintains that developing countries should just remove protectionist barriers and engage in shifting resources from non-competitive to more competitive outward-oriented sectors. ${ }^{8}$ Regarding the roles of public and private sectors, the Washington Consensus clearly prefers the latter, one of the major argument being the problem of rent-seeking in the former. As a result of that position, privatisation is recommended as a desired policy direction. ${ }^{10}$ The major rationale for privatisation is the belief that private industry has better management 
than was usual in state enterprises where managers could not hope for a direct benefit from the profit they contributed to create. The Washington Consensus is very positive about FDI as it is supposed to bring needed capital, skills, and know-how, either producing goods needed for domestic market or contributing new exports. ${ }^{11}$ And finally, this development economics current is generally supportive of financial liberalisation and financial sector development, as they are believed to bring developing countries closer to development, i.e. to foster economic growth. ${ }^{12}$

The post-Washington Consensus was able to embrace and mainstream the critique of the Washington Consensus without having to abandon basic methodological and ideological fundaments of the standard neoclassical economic theory. Nevertheless, its version of development receives adjectives sustainable, egalitarian, and democratic (Stiglitz 1998a: 31). To different extents, authors listed in this development economics current depart from the unconditional support for free international trade. Some admit the difference between the modelled free market ideal and the reality including its market imperfections. ${ }^{13}$ The more radical ones conclude that openness of a country is an irrelevant factor in the quest for growth and development, or explicitly acknowledge that some sort of industrial or protectionist policies might be desirable. ${ }^{14}$ When it comes to the discussion on the role of public and private sector in development, the post-Washington Consensus allows for a significantly bigger role for the government than its predecessor. The post-Washington Consensus development economics current of thinking is generally supportive of foreign direct investment, but suggests that there is a need for differentiation between enclave FDI and genuinely beneficial FDI. ${ }^{15}$ An important component of the post-Washington Consensus is the stress on strong but wisely regulated financial sectors.

Heterodox development economics represents the most varied but generally also most critical group. It draws much from the early development structuralist economics tradition, but includes also institutionalist, evolutionary, Marxist, post-Keynesian, ecological and other 'non-neoclassical' currents of economic thinking. As opposed to the static concept of neoclassical economics, heterodox approaches are
${ }^{11}$ See Williamson (1990), and

Moran (1999: 19 - 20).

${ }^{12}$ See for example

Bencivenga and Smith (1991), Bencivenga et al. (1995), and Beck et al. (1999).

${ }^{13}$ See Stiglitz (1998a, 1998b), and Krugman $(1987,1995)$.

${ }^{14}$ See for example Rodriguez and Rodrik (1999), and Rodrik (2008).

${ }^{15}$ See for example in Stiglitz (1998b: 27). 
dynamic and emphasise the element of change in their models. While structuralist heterodox economists keep to the early structuralist claim that underdevelopment in developing countries is due to the lack of capitalist development, dependency theorists highlight the historically perpetuated exploitation of the periphery by the centre, including different forms of extraction of economic surplus and mechanisms of surplus transfer to the centre. ${ }^{16}$ International trade regime of unequal exchange is a crucial factor of the above mentioned relations and trade-related exploitation represents one of the concrete mechanisms of how dependency and underdevelopment of the periphery is maintained. ${ }^{17}$ Accordingly, dependency theorists argued for rather

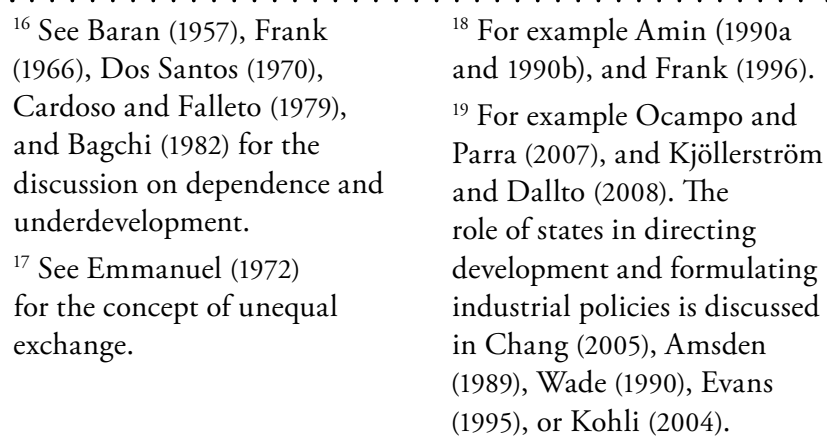

revolutionary solutions (delinking, self-reliance, south-south cooperation, nationalisation, land reform). ${ }^{18}$ To break from the dependent situation, less radical heterodox development theorists advocated only progressive reforms to the system (industrial development oriented to mass production and consumption, equal redistribution of income) and called for export diversification into higher quality products, and a very strong government oversight and regulation including active following of industrial and technological policies. ${ }^{19}$ The position of heterodox economists towards FDI varies from a complete rejection by dependency theorists to acceptance with reservations by economists working in the structuralist tradition. And finally, government control over the financial sector is essential - its operations should be stable and subordinated to genuine development objectives.

There are several focal areas and sectors where EIB invests in developing countries. They are important from the development economics aspect, as the four currents view them often differently. This paper answers the following questions in the Bank's development discourse: 
- What is development and how can it be achieved?

- What are the impacts of free international trade on development?

- How should developing countries dispose of their natural resources?

- What are the roles of private and public sectors in fostering development?

- What are the impacts of foreign direct investment on development?

- What is the importance of financial services sector for development?

Answers to these questions manifest themselves in EIB's development-related texts. After comparing the mutually often contentious answers provided by the four currents with the answers presented in EIB's development related texts, the paper identifies affinities between the Bank's discourse and one or more development theories. The greatest challenge of the paper is thus to identify, formally reconstruct and interpret EIB's 'cognitive map' of developmental thinking and writing.

Methods and approach used in this paper draw primarily from the work of Norman Fairclough (2003) on critical discourse analysis (CDA). CDA focuses on the dialectical relationships between discourse and other elements of social practices. Texts are elements of social events, and the meanings of texts can have causal effects and bring about changes. One type of effect, namely ideological effects, is crucial for this paper as they can contribute to establishing, maintaining and changing social relations of power, domination and exploitation. It is in this context of power relations that the EIB texts related to development will be scrutinised, and the paper will also try to decipher the ideological assumptions they rest on. This paper focuses on the 'interdiscursive' and 'intertextual' aspects of EIB's texts - reflecting how they draw upon and articulate together different discourses, and draw upon, incorporate, recontextualise and dialogue with other texts respectively. Finally, this paper subscribes to Fairclough's notion of 'critical social science' - social science which is motivated by the aim of providing a scientific basis for a critical questioning of social life in moral and political terms, e.g. in terms of social justice and power.

The notions 'hegemony' and 'ideology' play a crucial role in the 
paper. The relationship between discourse and hegemony, as applied in the paper, is based on Gramsci (1971). His analysis is useful in portraying discourse as a practice of power and domination. According to Chouliaraki and Fairclough (1999: 24), Gramsci's 'hegemony' emphasises the importance of ideology in achieving and maintaining relations of domination by consent rather than coercion. Discourses assume a certain power over how individuals think and behave (Harvey 1996: 83). Hegemonic discourse is thus a discourse that makes certain vision look more 'natural' than others and is internalised by actors without them knowing that they yield to a particular ideology and power interests. When referring to ideology, the paper draws mainly on those authors who focus on ideas of true and false cognition, where ideology is seen as illusion, distortion and mystification. However, ideology does not refer only to belief systems, but to questions of power, and particularly to legitimating the power of dominant social groups or classes (Eagleton 1991: 3-6). Ideology thus stands for meanings applied to sustain relations of domination.

\section{3_EIB's theoretical inspirations and discursive practices}

In its documents and statements, EIB does not openly identify itself with any of the development economics theories. In its few analytical papers, it rarely refers to academic sources. Its outright identification with some of the development economic traditions therefore cannot be made cut and dry. Nevertheless, indications exist, according to which it is feasible to analyse where EIB draws its inspirations from when promoting development. Some issues are highlighted, some omitted, some are taken for granted, and some ignored. Closer scrutiny on these discursive practices enables to reveal theoretical justifications behind the thoughts on how to promote 'development' and what 'development' actually stands for. With EIB not referring to academic work, the analysis of the EIB discourse in this paper will thus seek to decipher implicit development arguments provided by EIB and classify them in the framework of development economics theories. In the following section, the EIB's developmental reasoning is analysed where several issues pop up and are presented as focal. The section introduces the areas of economic 
growth, international trade, extractive industries, the role of public and private sectors, FDI, and financial sector as presented by EIB, and seeks to discuss in what development tradition they fall respectively.

\section{1_Economic growth}

First of all, there is a very strong belief emanating practically from all the development-related EIB documents, that in order to achieve development objectives, economic growth is absolutely critical. At some places it even seems that the notions 'development' and 'economic growth' are used interchangeably. Similarly, poverty reduction (or alleviation) is referred to as the major development objective. The line of thinking reflected in the EIB documents and statements can be therefore basically summed up as follows: economic growth reduces poverty and brings development. What one can see here is how two potentially contradictory goals - 'development' (beneficial primarily for the target countries) and 'investments' (beneficial primarily for the Bank and its shareholders) are carefully managed - the potential conflict is downplayed, i.e. is taken care of by being presented 'development investments' as a win-win deal for both parties. The interdiscursive reference to 'economical and financial viability of projects' EIB supports ${ }^{20}$ is an example of how the discourse of development is 'recontextualised' in the financiers' discourse of profitability. ${ }^{21}$

EIB thinks of at least three

concrete mechanisms how the economic growth translates to wellbeing or development. First, the EIB financed projects are supposed to have "a favourable impact on economic growth and, eventually on income generation" and the increased income gets people out of poverty. ${ }^{22}$ Second, "incremental incomes can be taxed, providing resources for the sustainable financing of direct poverty alleviation measures (income transfers and/or provision of goods and services to the poor)". ${ }^{23}$ The third mechanism is the improved access to productive resources. within the context of the latter, and transforming it in particular ways in the process."

22 The EIB - a development partner and the Millennium Development Goals.

${ }^{23}$ Development Impact Assessment Framework of Investment Facility Projects, p. 1. 
For example, an EIB-financed project in Brazil has to "generate significant export revenues, thereby having a positive impact on Brazil's balance of payments". ${ }^{24}$ To sum up, more individual income, more tax revenues, and more export revenues represent the reflection of economic growth and its positive impact on development, the Bank would maintain.

On the first sight, one may tend to trace the EIB's one-dimensional fixation on economic growth back to the earliest development economists of 1950s. And indeed, development theorists such as Rosenstein-Rodan (1943), Nurkse (1961), or Hirschman (1958), or the World Bank in 1950s and 1960s, claimed similarly to EIB that economic growth is a primary and absolutely essential precondition for development. However, unlike the referred to development economists, EIB does not at all mention socio- economic structural transformation, industrialisation, modernisation, etc. as important ingredients that would form its growth strategy. If one considers what will be discussed in more detail further in the paper, namely the fact that EIB supports development lead by the private sector, not by the state, and that the Bank supports the model of developing economies based on unprocessed exports ${ }^{25}$, it can be seen that the inspiration of EIB in the early development economics is only a deceptive appearance. The abovementioned reflects rather an inspiration in the Washington Consensus. ${ }^{26} \mathrm{EIB}$ seems to assume that economic growth will be just a natural result of prudent macroeconomic policies, outward orientation, and free-market capitalism. And if EIB stresses its unconditional dedication to economic growth more than is usual in the Washington Consensus tradition

\section{${ }^{24}$ Veracel Pulp Mill \\ Project, Brazil.}

${ }^{25}$ Nowhere in the EIB texts is it possible to find a significant statement that EIB would like to support more added-value, high-quality, sophisticated, and diversified exports. On the contrary, instances of opposite statements - support for primary exports - are many. A webtext titled EIB financing for mining projects, for example, states that "projects in the mining sector are usually prime projects for bringing value to indigenous natural resources, increasing export revenues and generating fiscal income for the country through royalties and corporate taxes. Moreover these projects create permanent - direct and indirect - jobs and provide training that contributes to local skills."

${ }^{26}$ See Williamson (1990),

Krueger (1974, 1997),

Bhagwati and Srinivasan (2002), Lal (2006), Berg (1981). 
(and thus might create the wrong impression of being inspired by the earliest development economics), then it can be explained rather by a reference to its imperative logic as an investment bank; the Bank tries to maximise the return on its investments which is best achieved under the conditions of fast economic growth. ${ }^{27}$

\section{2_International economic regime}

EIB is primarily an investment bank and, unlike the World Bank and other regional development banks, it does not invest in programmes of structural reforms and transformations. Direct project investments, such as the projects involving FDI (discussed below), are therefore more crucial in the Bank's lending activities than, say, engaging in promotion of free trade, market liberalisation, or economic deregulation. This is not the EIB's business. However, one can identify moments in the Bank's discourse, where - despite of the fact that they are not promoted directly by financing - liberal economic policies are portrayed as desirable, while this absolutely cannot be said about the ones that employ interventionist measures.

EIB for example claims it is "helping to attain the objectives of the Euro-Mediterranean Partnership with a view to the creation of a free trade area by $2010 " .{ }^{28}$ In the same region, the Bank's role is not only the support for the free trade, but it is also involved in "helping to liberalise the financial sectors". ${ }^{29}$ The EIB's president Philippe Maystadt openly states that, among other things, the Bank's "efforts centre on fostering economic liberalisation". ${ }^{30}$

There is only one current of development economics where free international trade is taken as desirable

\begin{tabular}{|c|c|c|c|}
\hline $\begin{array}{l}{ }^{27} \text { It is a hypothesis of this } \\
\text { paper that EIB is primarily } \\
\text { an investment bank to which } \\
\text { development mandates were } \\
\text { attached from various (mostly } \\
\text { political) reasons. If one } \\
\text { accepts this premise, then it } \\
\text { looks quite understable that } \\
\text { the Bank tries to textually } \\
\text { manage potential conflict }\end{array}$ & $\begin{array}{l}\text { between development } \\
\text { objectives and investment } \\
\text { imperatives by presenting } \\
\text { them as harmonious and } \\
\text { mutually reinforcing in its } \\
\text { development discourse. } \\
{ }^{28} \text { EIB Group's } 2007 \text { Annual } \\
\text { Report, p. } 69 \text {. Although this } \\
\text { passage is quoted directly } \\
\text { from the EIB text, it is an }\end{array}$ & $\begin{array}{l}\text { obvious reference to the goal } \\
\text { of the EU, see for example } \\
\text { EC's text Euro-Mediterranean } \\
\text { trade relations are healthy } \\
\text { and growing. It is a practical } \\
\text { example of intertextuality, } \\
\text { and also of how discourses } \\
\text { 'migrate' among institutions. } \\
\text { This phenomenon can be } \\
\text { also interpreted in the sense }\end{array}$ & $\begin{array}{l}\text { that the Bank is not entirely } \\
\text { autonomous, and therefore } \\
\text { not completely accountable } \\
\text { for its own activities - that any } \\
\text { activity is a result of some form } \\
\text { of 'European governance.' } \\
{ }^{29} \text { EIB Group's } 1999 \text { Annual } \\
\text { Report, p. } 40 . \\
{ }^{30} \text { EIB Group's } 2001 \text { Annual } \\
\text { Report, p. } 5 \text {. }\end{array}$ \\
\hline
\end{tabular}


and practically non-problematic, namely the Washington Consensus.

All the remaining traditions are more or less critical to it. A very reserved position towards unlimited economic openness is self-evident in the heterodox approaches to development economics. International aspect of development was not so prominent in the whole body of early development economics literature, but where it was present, then it was analysed critically in terms of structural asymmetries between the centre and periphery. ${ }^{31}$ The post-Washington Consensus authors are closest to favouring economic openness in principle, but they are able to recognise market imperfections, and therefore depart to a greater or lesser extent from the free-trade mantra. ${ }^{32}$ The EIB's inspiration in the Washington Consensus thus seems to be clear.

\section{3_Extractive industries}

As just presented, EIB fully supports the idea of free trade and economic

${ }^{31}$ See Prebisch (1948), Singer (1950), Lewis (1954).

32 See Stiglitz (2001), Krugman (1986), Rodriguez and Rodrik (1999), Rodrik (2008).

\footnotetext{
33 The Washington Consensus position in this area is discussed, for example, in Ocampo and Parra (2007: 113), and Menzel (1993: 134).

${ }^{34}$ See for example Prebisch (1948), Singer (1950), Stiglitz (2001).
}

openness. One particular area where EIB invests with the aim of adding value to development objectives, and with a view that raw material exports are desirable for development, is mining. EIB believes that revenues from mining exports will earn developing countries necessary foreign currency and the state budget will profit from the related taxes. The Bank also relies that jobs created in the mining sector will improve the social situation of the poor. Absolutely no critical mention of potential clash between development objectives and economic model based on raw material exports serves as yet another example of EIB's inspiration in the Washington Consensus development economics thinking. ${ }^{33}$ All the remaining development economics traditions contain at least some critical discussions on mining as an appropriate economic development strategy for developing countries. ${ }^{34}$

\section{4_Public vs. private sector investments}

Previous sections of the paper have aimed to present EIB's devotion to the concept of economic growth (achieved via free international trade and primary products export promotion) that leads routinely to poverty reduction, and thus equals development. The question may arise what is the main channel 
of EIB's contribution to this concept of development; or, in other words, how EIB invests to achieve the stated development objectives. The answer is quite clear - EIB supports private sector in developing countries. Despite the fact that EIB does not try to conceal this approach, it will be worthy to analyse the developmental rationale and inspirations behind it. The logic behind EIB's thinking on development is best illustrated in the scheme (Chart 2) presented by an EIB senior investment officer, in which she visualises her understanding of the Bank's mandate under the Cotonou Agreement: developing private sector leads to economic growth, and economic growth reduces poverty.

Privatisation can be said to be another objective (and closely connected to the previous one) through which EIB seeks to contribute to development. It is not usual that EIB would provide some elaborate justification for its developmental reasoning or would engage in discussing the historical development of the development economics discipline. However, in one of such rare occasions, the Bank tries to make a historical excursus into understanding the role and performance of private sector versus public sector. ${ }^{35}$

\section{Chart 2: ElB supporting development - visualisation}

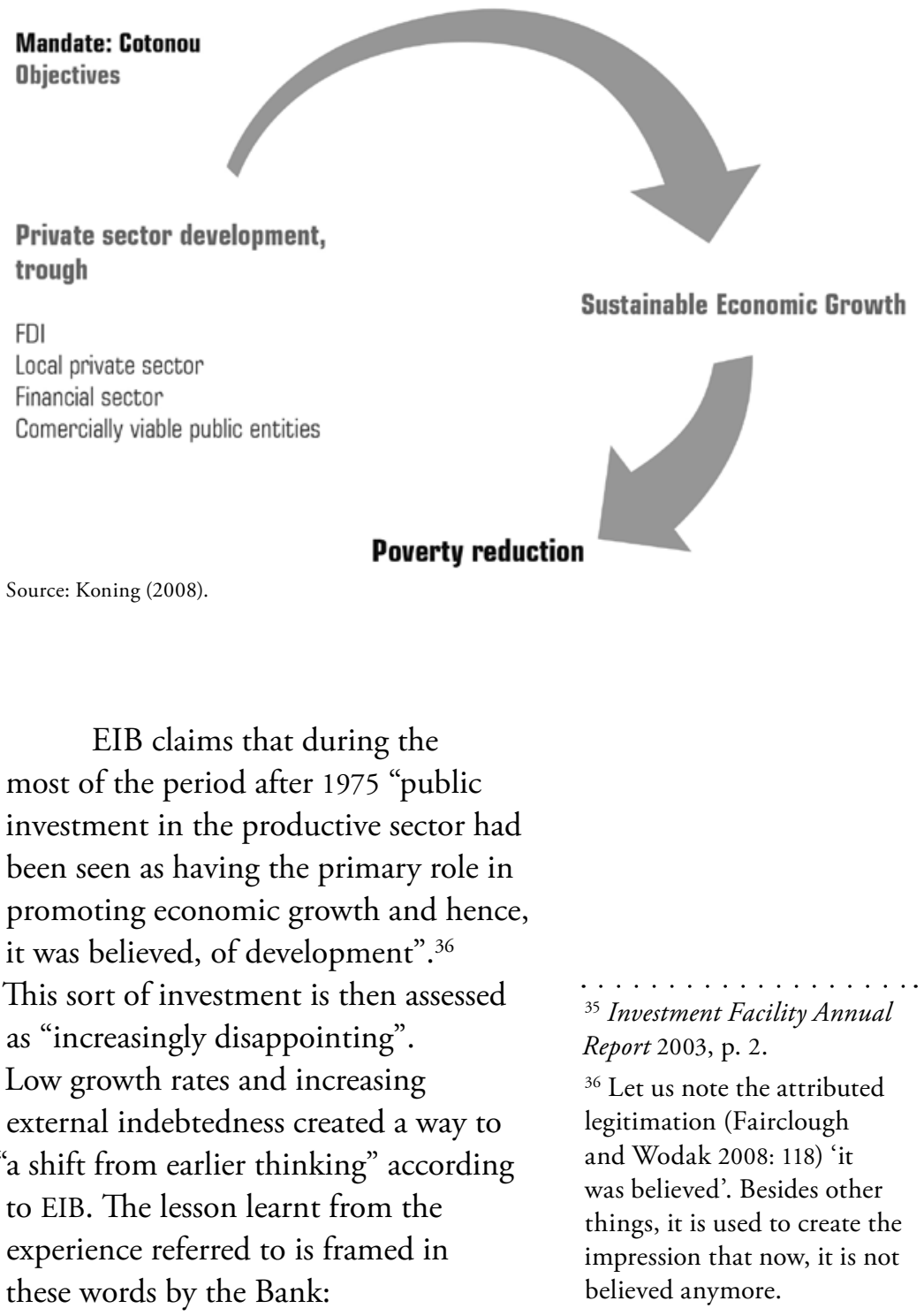


Hence the development paradigm began to change; a new approach gave greater prominence to the role of the private sector as the principal source of economic growth. In a shift from earlier thinking, it was acknowledged that growth and development could not rely solely on government planning but also depended on encouraging private sector initiative. This meant, in turn, recognising the importance of market forces: private sector enterprise has to be competitive to survive, something which had not always been a concern for public investment.

\section{Several important observations} need to be made here. First, it is highly probable that the 'new approach' EIB is referring to is what has later become known as the Washington Consensus replacing the early development economics thinking that emerged after the World War II. Second, given the tone and formulations, and what

\footnotetext{
${ }^{37}$ Note the use of an increasingly popular term 'governance'. Just the use of this notion can be interpreted as an affiliation to a particular discourse. According to Fairclough (2003: 129),
}

'governance' belongs to the neoliberal discourse, unlike, for example, Keynesian 'governing'. For more detail on governing, governance, and governmentality, see Rose (1999: Chapter 1). precedes this quote and what follows after it, it can be argued that EIB is not solely referring to the historical development of 'public vs. private' views but agrees with this 'new approach' and avows it. For example, instead of the distancing phrase 'it was believed' used in the previous statement where EIB does not identify itself with the phenomenon referred to, one can find confirmatory phrases of attributed legitimation such as 'it was acknowledged' or 'recognising'; the modality is very positive here - EIB as the author is in a positive relationship with the representation, and finds it corresponding to the perceived truth. And third, the reason for the preference for the private sector over the public one is identified - it is competitiveness.

Not as prominent in its development reasoning as the other areas analysed here, but still important and more and more referred to - is the issue of corporate governance ${ }^{37}$, which is closely related to the previous discussion on the role of private and public sectors. It is a relatively modern concept, and for EIB even more so. The Bank has adopted the discourse and efforts of other IFIs, most notably the World Bank, which introduced the concept earlier. EIB's commitment to the voluntary concept 
of self-regulating corporations is quite easy to document. ${ }^{38}$

The inspiration by the postWashington Consensus 'good governance' discourse as practised particularly by the World Bank since 1990 s is quite clear here. ${ }^{39}$ By joining this discourse, EIB is not being inconsistent with its previously documented pro-private development discourse inspired in the Washington Consensus. The Bank is still sceptical about the public sector and identifies the government interventions in developing countries as a part of the problem; however, it is ready to reach out for a more sophisticated and nuanced argumentation in order to back this position. The governance discourse provides exactly this - by introducing the concept where the government fails, and therefore a whole range of other stakeholders (business, civil society organisations, local communities, academia etc.) must be involved in 'governing', it is able to undermine the position of public sector more subtly.

Given the above analysed points, one can immediately exclude early development economics and heterodox development economics as potential sources of inspiration for EIB in the issue of state vs. private sector preference..$^{40}$ Both of them ascribe much greater developmental role and significance to the state. The post-Washington Consensus argues for a partnership and coordination between the public and private sectors in their developmental mission. How this partnership and coordination should precisely look like is open to interpretation - the prominent representative of this theoretical current uses exactly the same wording as EIB when he states that "creating the enabling environment for the private sector" is one of the unique functions of the public sector (Stiglitz 1998b: 19). Nevertheless, he - and it is representative for the whole group of theorist classed under the postWashington Consensus umbrella - the 'public vs. private' debate, EIB openly distances itself from the early development economics. Similarly, identifying the 'disappointing' public sector performance and excessive government intervention as the reason of the 'lost decade' is an obvious (though not explicitly credited to) reference to Anne Krueger (for example 1974) and other Washington Consensus theorists. 
${ }_{11}$ European Investment Bank financing in Asia and Latin America, p. 2.

${ }^{42}$ Ibid., p. 5.

${ }^{43}$ See Dos Santos (1970: $233-234)$, Becker and Schwank (2009), Amin (1974), or Ocampo, Kregel and Griffith-Jones (2007: $26-34)$. A separate set of arguments related to FDI regards its alleged positive role in technology transfer and technological spillovers. Heterodox critique why technology might not flow and 'spill over' so easily to and in developing countries is presented in Lall (2003) and Deraniyagala (2006). in the same breath adds other significant functions for the public sector that clearly distinguish them from the Washington Consensus. Furthermore, the post-Washington Consensus is critical of privatisation without competition and regulation (Stiglitz 1998a: 20 - 24). It thus seems that EIB's development discourse related to the public vs. private sector preference overlaps mostly with the development arguments of the Washington Consensus. It departs from it only when introducing the issue of corporate governance, where this reference is clearly attributable to the post-Washington Consensus tradition.

\section{5_Foreign direct investment}

After presenting EIB's preference for the private sector due to its higher efficiency, the focus will shift to the question of how the positive effect of private sector on development practically works according to EIB. In order to foster the economic development of the recipient partner countries, EIB continues

\footnotetext{
"to support the EU's presence in ALA through the financing of FDI and the transfer of technology and know-how from Europe". ${ }^{41}$
}

The Bank's president proclaimed that EIB's efforts outside EU

"centre on fostering economic
liberalisation, encouraging the
transfer of capital and know-how
through foreign direct investment". ${ }^{42}$

The Bank's line of argument can be basically stated as follows: EIB supports FDI projects in developing countries; it thus contributes directly to economic growth and indirectly to the transfer of technologies and know-how; these direct influences and indirect spillovers will be beneficial for the economy of the target country. There is absolutely no mention of potentially negative aspects of FDI in the EIB documents.

The only development economics tradition with an unreserved position towards FDI is the Washington Consensus; the other three currents take up a differentiated stance. Heterodox development economists are the most critical towards FDI. ${ }^{43}$ Fairly critical position was assumed also by most of the early development economists - perhaps with the exception of Gerschenkron (1962: 9), who was an optimist regarding FDI - particularly by structuralists. Just to remind - they argued that FDI 
tended to create dual economies with advanced export sector within primitive subsistence sectors, and thus in fact resulted in locking-in of the domestic economy in underdevelopment. ${ }^{44}$ The post-Washington Consensus also differentiates between the 'enclave'type of FDI and the genuinely beneficial foreign direct investments that can advance and integrate developing societies (Stiglitz 1998b: 27). The only unanimous supporters of FDI can be found within the tradition of the Washington Consensus, and - as EIB does not ever even mentions potential problems with FDI, or does not state that it seeks to promote only the projects involving the truly beneficial FDI and shuns supporting the 'enclave' FDI projects - one can conclude that the Bank's development discourse regarding FDI is most compatible exactly with this development economics current.

\section{6_Financial sector development}

Another crucial sector in developing countries EIB is willing to invest in with the aim of contributing to development objectives is the sector of financial services (also present in Chart 2). For the Bank, financial sectors in partner countries outside EU are

\section{"a strategic instrument to achieve its stated objective of promoting economic growth through private sector development". ${ }^{45}$}

Within the financial sector, a special role is played by microfinance. First, the Bank considers microfinance an important instrument in the efforts to alleviate poverty. Second, EIB is self-confident regarding its expertise in this sector. And third, the Bank wants to help poor by supporting microfinance initiatives, but also believes in its signalling power to attract other investors. ${ }^{46}$

Financial sector development in developing countries does not play a pivotal role in the early development economics ${ }^{47}$ or in the heterodox development economics thinking. ${ }^{48}$ It does so in the other two currents.

$\begin{array}{ll}{ }^{44} \text { See Singer (1950: 484-485), } & \begin{array}{l}\text { importance of financial sector } \\ \text { in development. }\end{array} \\ \text { Lewis (1954: 27). } & \begin{array}{l}{ }^{48} \text { It has to be noted that } \\ \text { financial issues play an }\end{array} \\ { }^{45} \text { Economic report on partner } & \text { important role for several } \\ \text { the Development Economics } & \text { contemporary heterodox } \\ \text { Advisory Service (DEAS), p. } 14 . & \text { development economists, but } \\ { }^{46} \text { EIB Group's 2007 Annual } & \text { their critical observations are } \\ \text { Report, p. } 45 . & \text { most unlikely to be found to } \\ { }^{47} \text { The only exception is } & \text { have a reflection in the EIB } \\ \text { again Gerschenkron (1962: } & \end{array}$


${ }^{49}$ An inspiration was drawn for example from the socalled financial repression analysis by Shaw (1973) and McKinnon (1973).

${ }^{50}$ Economic report on partner countries 2007. A report by the Development Economics Advisory Service (DEAS), p. 16.

${ }^{51}$ Ibid., p. 21.
Washington Consensus was generally supportive of financial liberalisation and financial sector development, as they were believed to bring developing countries closer to development, i.e. to foster economic growth. ${ }^{49}$ The postWashington Consensus acknowledges the importance of financial system for growth and development but, unlike its predecessor, insists that an accompanying sound legal framework combined with financial sector regulation and oversight are essential (Stiglitz 1998a: 14 - 17). Both positions can be found in the EIB texts related to development - the former in most of the Bank's texts, whereas the latter is presented in the DEAS economic report of 2006.

\section{7_ElB's Development Economics Advisory Service reports}

DEAS reports are being referred to several times in this paper. The last section of the paper aims to discuss them in more detail as they have a specific position among all the EIB documents. As already indicated, they are not prepared by the Bank's regular staff, but by experts from Development Economics Advisory Service. This analytical unit works under EIB but it is not clear whether its only competence is to publish the reports and provide other consultancy services. This question is important as the DEAS reports are not only relatively best elaborated papers on the issue of development, but also seem to depart from the EIB 'mainstream' development discourse at several points.

The authors of the DEAS report from 2007 are, for example, quite critical towards the Washington Consensus.

They affirmatively refer to the critique of its 'laundry list' approach

\section{"which resulted in a lack of focus and a failure to target aid according to the specific needs of the recipients." 50}

The authors further state that the result of Washington Consensus was neither a balanced programme of reforms nor an attempt to address the constraints on growth. To put it simply, "the programme's track record was disappointing [for example in Eastern Europe and sub-Saharan Africa]". ${ }^{51}$ And what makes the report even more exceptional is its reference to development economists such as Rodrik, Velasco, or Collier. First, just the fact that the authors establish a dialogue with development academia, and second, that they positively refer to critical concepts (e.g. the one of Rodrik), makes the report unique 
amidst the body of EIB's texts related to development.

In another report, one can find a relatively critical approach towards the effect of financial development on economic growth. Whereas the usual result from literature is "that financial development has a positive, monotonic effect on growth", the authors of the report conclude that

"financial development yields a strong positive effect on economic growth only once it has reached a certain critical threshold"

and until that point

\section{"the impact of further financial development on growth might actually be negative". 52}

Already in the introduction to this section, a comment was made that it is not sure to what extent the DEAS reports and their findings are reflected in other EIB documents and EIB activities. This is an example. Although the DEAS report concludes that financial development is beneficial for developing countries only after reaching a critical threshold, other documents by EIB and presumably EIB's activities, too - do not contain this reservation and promote financial sectors in developing countries unconditionally. It thus seems that the DEAS reports indeed fulfil just an advisory function and their relatively more nuanced observations stay ignored by the 'EIB mainstream'.

As can be seen from the two mentioned examples, the DEAS reports can be more critical, varied, and nuanced than the rest of the EIB documents. However - and despite the instances just referred to - the DEAS reports do not depart from the 'EIB mainstream' in many respects at all. As pointed out in the section on economic growth, the reports study only 'macroeconomic fundamentals' (GDP growth, inflation, fiscal balance, and current account balance) and neglect other indicators. A biased evaluation of some developments - such as an example of positive assessment of privatisation ${ }^{53}$ and negative 
judgement of interventionism ${ }^{54}-$ was often obvious.

If one examines the selection of the topic covered in Part II of the reports ${ }^{55}$, an approximate pattern stemming from ideological inspirations can be identified. The first report the one of 2005 - selects two topics: managing the risks of natural disasters in developing countries; and local currency bond market developments in Mediterranean and ACP countries.

The former issue is described in terms of its rising costs during last thirty years and analysed in terms of what can be done. The report investigates neither the structural reasons why more and more people are vulnerable to natural disasters, nor global context of responsibilities for the situation, nor any similar issue. Besides prevention (that should be taken care by public authorities), the report's focus is insurance against the natural disasters related risks. It promotes tools such as spreading these risks via insurance to global capital markets, securitisation of disaster liabilities, introduction of weather-derivatives, etc. The report applies phrases such as "agents dispose of limited information" 56 or operates with the terminology used in gametheoretical approaches, e.g. 'Samaritan Dilemma' ${ }^{57}$. All this - reluctance to analyse structural and global context of the problem, reliance on privatebased insurance via capital markets, methodological individualism and reference to game theory - suggests that the authors of the analysis think in the scope of neoclassical economics. Their application of Samaritan Dilemma

\footnotetext{
${ }^{54}$ When reporting on the developments in Argentina and Venezuela in 2006, EIB's document uses an evaluative phrasing that these countries "were experimenting with populist policies and using price controls." Economic report on partner countries 2006. A report by the Development Economics
} Advisory Service (DEAS), pp. $11-12$.

\author{
55 The DEAS reports consist \\ of two parts. Part I provides \\ general economic overview \\ of the partner countries. Part \\ II always focuses on a partial \\ issue selected by authors. \\ ${ }^{56}$ Economic report on partner \\ countries 2005. A report by \\ the Development Economics \\ Advisory Service (DEAS), p. 16. \\ 57 The term 'Samaritan's \\ Dilemma' was coined by \\ the right-wing economist \\ James M. Buchanan (1975). \\ In this game theoretical \\ model, Buchanan refers to \\ situations when altruism can \\ induce adverse behaviour \\ of potential recipients. \\ Translated to development \\ economics, donor countries' \\ efforts can actually serve to
}

\author{
give developing countries \\ incentives to continue in \\ behaviour that keeps them \\ in poverty. It is no surprise \\ that also other IFIs refer to \\ the term when analysing \\ natural disasters in developing \\ countries, see for example the \\ World Bank report (Raschky \\ and Schwindt 2009).
}


indicates that they are influenced by the post-Washington Consensus development economics tradition which - unlike the Washington Consensus with its universal and ahistorical applicability of mathematical models tries to bring history and institutional and other contexts (path dependence from multiple equilibria of the past) back in by using game theory. ${ }^{58}$

The latter selected issue of the 2005 DEAS report is local currency bond market developments. The 2006 report focuses on the financial sectors in middle income partner countries. Part II of the 2008 report is titled "Scaling up microfinance". 59 The dominance of the finance sector as the object of the DEAS reports analysis cannot be overlooked. It is not the aim of this paper to argue that financial sector is irrelevant or harmful to developing countries. Most likely it is not the case, and developing countries can benefit from it under certain circumstances. However, there is no consensus regarding the question whether other areas - for example infrastructure, manufacturing, agriculture, education, or other areas where EIB invests - are less important than the financial sector. Many development economists would argue the contrary. The point here is that most of the neoclassical development economists stress the importance of financial sectors in developing countries. And so do the development economists at the EIB's DEAS.

The first conclusion is related to the ideological inspirations of the DEAS reports. As already stated, they are more complex than the rest of the EIB development related texts, and it is therefore also more difficult to distil a coherent ideological message from them. It is clear that one would have real difficulties finding an inspiration in the early development economics or heterodox development economics in the reports. Instances of an inspiration in the Washington Consensus and the post-Washington Consensus, on the other hand, are many. It is hard to say which of these traditions prevails. This paper concludes that the DEAS reports represent a relatively progressive (still within the limits of neoclassical economics) voice within the Bank (in fact the only one) and resemble the products of the World Bank's research departments, from which they obviously learn and to which they often refer. Both the EIB's DEAS and the research groups of the World Bank move on the edge when they have to serve banking institutions
58 For an eloquent discussion of (not only) the postWashington Consensus's approach to economic history, see Milonakis (2006).

${ }^{59}$ Economic report on partner countries 2008. A report by the Development Economics Advisory Service (DEAS), pp. $22-30$. 
${ }^{60}$ See for example in Fine and Sundaram (2006). with straightforward 'development' activities (the Washington Consensus) under critique, and have to provide them with a relatively sophisticated legitimation (the post-Washington Consensus) of these activities that will resist the criticism. As discussed elsewhere in academic literature ${ }^{60}$, the concrete operation and activities of global development financiers are changing very slowly, and what is developing more dynamically is just the 'new development economics' (or the post-Washington Consensus) discourse that serves to mask the stagnant reality. There are reasons to believe DEAS and its reports is a part of this phenomenon.

The second conclusion - or rather a set of concluding thoughts and questions - regarding the DEAS reports relates to their role and function in EIB's development discourse. The slight dissonance between them and other EIB texts reflects the fact that the Bank is not a monolithic institution, and that it can look to and act differently towards various actors in the field (Kobová 2009). As the reports are not fully in line with the rest of EIB texts, one is tempted to ask to whom they are addressed. The analysed disagreement on financial development suggests that the EIB management does not act up to the findings of the experts from DEAS; furthermore, the DEAS reports are made public. These two facts might make us think that rather than to the inside of the Bank, the reports are addressed to the outside. And although they sometimes question the dominant part of the development discourse practised by EIB, it can be argued they are part of it - they serve to raise the expert and scientific credit of the Bank and thus help to legitimise its activity in the area of development.

\section{8_The World Bank as an institutional source of inspiration in development discourse}

Despite some level of expertise that was just mentioned, and despite its clear development role and impacts,EIB - to the best of the knowledge of this paper's author - has not elaborated any genuine research or analysis on the issue of development. The relatively most elaborated documents are the previously analysed DEAS economic reports, but still - they contain only rather a short report on economic condition of developing countries and then very narrow and limited, fewpages-long literature research on selected issues. In other documents and statements, EIB limits itself to vague definitions; assumes several economic 
arguments and clichés as given and unquestioned facts; draws arguments from a set of steadfast representations and imaginaries; and handles the issue of development rather simplistically. Regarding the use of research in development economics, EIB almost does not reflect its existence. The missing link to academic expertise in the field of development, this poverty of development economics at EIB, is indeed surprising in itself, given the fact that EIB is engaging in development. With this striking absence of textual dialogue with academia, but also with other potentially relevant actors (local communities, NGOs etc.), one might ask where from actually EIB draws the minimal knowledge necessary to at least label its investments as 'development investments'.

One potential answer to the raised question is: from the developmental discourse practised by other IFIs, and particularly by the World Bank. Indeed, if there is enough intertextual dialogue with other than EIB's own (or European Union's) texts, than it is with those authored by the World Bank or, in general, by the global and regional development financiers. As far as one can judge, practically all the references to the World Bank are positive - they refer to the partnerships and cooperation between the two banks in projects, initiatives, action plans, programmes, memoranda of understanding etc.

The cooperation between EIB and the World Bank in the area of development has a long history. The World Bank in its first decade was managed as an investment bank (Birdsall and Londoño 1997: 6). The World Bank's statutes and organisation served as a model for those of EIB when it was being created. Collaboration between the two institutions was most significant outside Europe following decolonisation. Close links at the staff level among specialists, similarity in the format of investment documents, exchange of information and statistics, etc. are all well documented in archives and "provide a clear picture of the close links that were established" (Bussière et al. 2008: 106). And indeed, the inspiration in the World Bank's developmental approach and discourse can be clearly sensed in many present EIB development related documents. Especially the issues of governance ('good governance', 'corporate governance', 'corporate social responsibility' and 'accountability') ${ }^{61}$ and of microfinance ${ }^{62}$ seem to be the

\footnotetext{
${ }^{61}$ See for example Statement on Corporate Social Responsibility. ${ }^{62}$ See for example European Investment Bank activities in Microfinance in Africa, the Caribbean and the Pacific.
} 
ones where EIB is active without having published much elaborate justification, and rather relying on and following the World Bank's greater experience and expertise (although the textual dialogue between the two banks is not always explicitly referenced). In conclusion, it has to be stated that despite the abovementioned close cooperation, EIB's development argumentation is indeed trivial if compared with the one of the World Bank, and that EIB gets by on justifying its investments outside the EU with a literal discoursive minimum.

\section{4_Conclusion}

The main points used by EIB in its development discourse can be summed up in the following way. First, EIB claims to contribute to development objectives by fostering economic growth in the target countries; in fact, economic growth is an inevitable precondition for development and the most crucial tool to achieve it according to the Bank. Second, EIB believes that the benefits of economic growth will trickle down to the poorest automatically, i.e. the growth will lift the poor from misery. Third, EIB unconditionally supports liberal economic regime, i.e. free trade, market liberalisation, and economic deregulation. Fourth, EIB considers raw material exports desirable for development. Fifth, EIB considers prosperous private sector as essential for economic growth, and supports privatisation in developing countries. Sixth, EIB supports FDI projects in developing countries as they are said to contribute directly to economic growth and indirectly to the transfer of technologies and know-how. Seventh, EIB sees finance sectors in developing countries as a strategic instrument to achieve the objective of promoting economic growth through private sector development.

As EIB's one-dimensional fixation on economic growth is not accompanied by calls for socio-economic structural transformation, but economic growth is rather assumed to naturally result from prudent macroeconomic policies, outward orientation, and free-market capitalism, it is clear that the Bank follows the development creed of Washington Consensus. This orientation is confirmed by EIB's ignorance of a variety of indicators in assessing economic conditions in developing countries. Support for a liberal economic regime, absolutely no critical reference to FDI, and no mention of potential clash between development 
objectives and economic model based on raw material exports further document that EIB's development discourse is directly influenced by the Washington Consensus development arguments. EIB's development discourse related to the public vs. private sector preference overlaps mostly with the development arguments of the Washington Consensus; it departs from it only when introducing the issue of corporate governance, where this reference is clearly attributable to the post-Washington Consensus tradition. Blending influence of the Washington Consensus and the post-Washington Consensus can be identified in the EIB's position towards the importance of finance sector development and microfinance in developing countries. One can thus conclude that overall, the Washington Consensus is the primary source of reference for the biggest part of the EIB's development discourse, whereas the postWashington Consensus supplements this discourse on several occasions.

Summing up the discoursive practices of EIB in the area of development, the following things have to be stated. Most of the EIB texts related to development are not dialogical - they contain almost no reference to academic sources or to the stakeholders in the target countries. The minimal intertextual reference that exists can be divided in three groups - 1. the one to fellow development financiers such as the World Bank, with a strong positive identification by EIB, 2. the one to the EU external action documents, in which rather than with development policies, EIB tends to affiliate itself with other geo-political priorities of the EU (such as free trade, FDI promotion), and 3. on a unique occasion - the one to contentious voices ('antglobalisation movement'), where distancing and questioning discourse is practised. EIB's development discourse is solid and presented confidently, with little questioning. This effect is achieved by assuming 'common ground' in the questions of development, and by a skilful textual management of potential conflicts between EIB's investment activity and development, which are eventually presented as mutually reinforcing. Such discoursive techniques serve the purpose of maintaining the ideological and hegemonic views of the Bank. However, EIB not only practices this kind of development discourse, but by promoting it as an important international actor in the field, it contributes to perpetuating and maintaining it on the global level. 
Finally, the selected theoretical conception of development happens to be compatible with the interests of the Bank's shareholders. Of course, there does not have to be a causal relationship here and it can be a mere coincidence. On the other hand, however, previous research on other IFIs has shown that declared development intentions of financing activities and the selected 'development ideology' of the Washington Consensus often served just to legitimise operations in developing countries and shareholders' interests in them. The background of this paper has been a hypothesis that also EIB's investments in developing countries pursue primarily EU Member States' interests, and the development discourse has emerged only recently as a reaction to mounting civil society criticism of EIB's investment impacts, without changing the existing practice, however. The hypothesis needs to be tested in a more comprehensive research. This paper has sought to make the first step by concluding that development economics thinking is underdeveloped and ideologised at EIB, the Bank's declared development intentions thus cannot be taken seriously, and the true motives for investing outside the EU need to be scrutinised critically. 


\section{References}

AMIN, SAMIR. 1974.

Accumulation on a World Scale: A Critique of the Theory of Underdevelopment. New York: Monthly Review Press.

AMIN, SAMIR. 1990a. Delinking: Towards a Polycentric World. London: Zed Books.

AMIN, SAMIR. $1990 \mathrm{~b}$. Maldevelopment: Anatomy of a Global Failure. Tokyo and London: United Nations University Press and Zed Books.

AMSDEN, ALICE H. 1989. Asia's next giant: South Korea and late industrialization. New York: Oxford University Press.

BAGCHI, AMIYA KUMAR. 1982. The political economy of underdevelopment. Cambridge University Press.

BARAN, PAUL A. 1957. The political economy of growth. New York: Monthly Review Press.

BAUER, PETER T. 1972. Dissent on Development. Cambridge: Harvard University Press.

BAUER, PETER T. 1984. Reality and Rhetoric: Studies in the Economics of Development. Cambridge: Harvard University Press.
BECK, THORSTEN, ASLI DEMIRGUC-KUNT, and ROSS LEVINE. 1999. A new database on financial development and structure. Washington DC: The World Bank.

BECKER, JOACHIM, and OLIVER SCHWANK. 2009.

"Theorien zum peripheren Kapitalismus." Pp. 117-146 in Heterodoxe Ökonomie. Marburg: Metropolis.

BENCIVENGA, VALERIE R., and BRUCE D. SMITH. 1991.

"Financial Intermediation and Endogenous Growth." Review of Economic Studies 58:195-209.

BENCIVENGA, VALERIE R., BRUCE D. SMITH, and ROSS M. STARR. 1995. "Transactions Costs, Technological Choice, and Endogenous Growth." Journal of Economic Theory 67:153-177.

BERG, ELLIOT. 1981. Accelerated development in Sub-Saharan Africa : an agenda for action. Washington DC: World Bank. BHAGWATI, JAGDISH, and T. N. SRINIVASAN. 2002. "Trade and Poverty in the Poor Countries." American Economic Review 92:180-183.
BIRDSALL, NANCY, and JUAN LUIS LONDOÑO. 1997. Asset Inequality Does Matter: Lessons from Latin America. Washington DC: Inter-American Development Bank http://ideas.repec.org/p/idb/ wpaper/4066.html (Accessed March 16, 2010).

BØÅs, MORTEN, and DESMOND MCNEILL, eds. 2004. Global institutions and development: framing the world? London: Routledge.

BUCHANAN, JAMES M. 1975.

"The Samaritan's Dilemma." in Altruism, Morality, and Economic Theory. New York: Russell Sage Foundation.

BUSSIÈRE, ÉRIC, MICHEL DUMOULIN, and ÉMILIE WILLAERT, eds. 2008. The Bank of the European Union. The EIB, 1958-2008. Luxembourg: European Investment Bank.

\section{CARDOSO, FERNANDO} HENRIQUE, and ENZO FALETTO. 1979. Dependency and Development in Latin America. Los Angeles and London: University of California Press.
CHANG, HA-JOON. 2005. Kicking Away the Ladder: Development Strategy in Historical Perspective. London: Anthem Press.

CHOULIARAKI, LILIE, and NORMAN FAIRCLOUGH. 1999. Discourse in Late Modernity: Rethinking Critical Discourse Analysis. Edinburgh: Edinburgh University Press.

COLAJACOMO, JAROSLAVA. 2005. The Development Impact of European Investment Bank (EIB) Lending Operations in the Cotonou and ALA Framework. Brussels: European Parliament.

COX, ROBERT W. 1996. Approaches to World Order. Cambridge: Cambridge University Press.

DERANIYAGALA, SONALI. 2006. "Analysis of Technology and Development: A Critical Review." Pp. 123-143 in The New Development Economics. After the Washington Consensus. New Delhi; London: Tulika Books \& Zed Books.

DOS SANTOS, THEOTONIO. 1970. "The Structure of Dependence." American Economic Review 60:231-36. 
EAGLETON, TERRY. 1991.

Ideology: an introduction.

London: Verso.

EMMANUEL, ARGHIRI. 1972.

Unequal Exchange: A Study of the Imperialism of Trade. New York: Monthly Review Press.

EVANS, PETER B. 1995.

Embedded autonomy: states and industrial transformation.

Princeton: Princeton

University Press.

FAIRCLOUGH, NORMAN. 2003. Analysing discourse: textual analysis for social research.

London, New York: Routledge.

FAIRCLOUGH, NORMAN, and RUTH WODAK. 2008. "The

Bologna Process and the Knowledge-Based Economy: A Critical Discourse Analysis Approach.” Pp. 109-125 in Education and the KnowledgeBased Economy in Europe. Rotterdam: Sense Publishers.

FINE, BEN, and JOMO KWAME SUNDARAM, eds. 2006. The new development economics. After the

Washington Consensus.

New Delhi; London: Tulika Books \& Zed Books.

FRANK, ANDRE GUNDER. 1966. The development of underdevelopment. Boston: New England Free Press.

FRANK, ANDRE GUNDER. 1996. "The Underdevelopment of Development." Chapter 2 in The Underdevelopment of Development: Essays in Honor of Andre Gunder Frank. Thousand Oaks: Sage Publications.
GALAL, AHMED, LEROY JONES, PANKAY TANDON, and ONGO VOGELSANG. 1994. Welfare Consequences of Selling Public Enterprises: An Empirical Analysis. Washington DC:

Oxford University Press for the World Bank.

GERSCHENKRON, ALEXANDER 1962. Economic backwardness in historical perspective. Cambridge: Belknap Press of Harvard University Press.

GRAMSCI, ANTONIO. 1971. Selections from the Prison Notebooks. edited by Quintin Hoare and Geoffrey Nowell Smith. New York:

International Publishers.

HARVEY, DAVID. 1996. Justice, nature and the geography of difference. Malden, Oxford, Carlton: Blackwell Publishing.

HIRSCHMAN, ALBERT O. 1958. The strategy of economic development. New Haven: Yale University Press.

KJÖLLERSTRÖM, MÓNICA, and KLEDIA DALLTO. 2008. "Natural resource-based industries: Prospects for Africa's agriculture." Pp. 119-181 in Industrial Development for the 21st Century. London, New York: Zed Books.

KOBOVÁ, L'UBICA. 2009. "Chapter Draft". E-mail exchange.

KOHLI, ATUL. 2004. Statedirected Development: Political Power and Industrialization in the Global Periphery. New York: Cambridge University Press.
KRUEGER, ANNE O. 1974. "The Political Economy of the RentSeeking Society." American Economic Review 64:291-303. KONING, MONIQUE. 2008. "The EIB's activities in ACP.” Berlin.

KRUEGER, ANNE O. 1997.

"Trade Policy and Economic Development: How We Learn.” The American Economic Review 87:1-22.

KRUGMAN, PAUL R. 1986. Strategic trade policy and the new international economics. Cambridge, MA: MIT Press.

KRUGMAN, PAUL R. 1987. "Is Free Trade Passe?." The Journal of Economic Perspectives 1:131-144.

KRUGMAN, PAUL R. 1995. "Cycles of Conventional Wisdom on Economic Development." International Affairs (Royal Institute of International Affairs 1944-) 71:717-732.

KUMWAMBA, PRINCE, and ANNE-SOPHIE SIMPERE. 2008. Soul mining: The EIB's role in the Tenke-Fungurume Mine, DRC. Brussels: Counter Balance http://www.counterbalanceeib.org/component/option,com datsogallery/Itemid,86/ file,tenke-study-en-web.pdf/ func, download/.

LAL, DEEPAK. 2006. Reviving the Invisible Hand: The Case for Classical Liberalism in the Twenty-first Century. Princeton: Princeton University Press.
LALL, SANJAYA. 2003.

"Technology and Industrial Development in an Era of Globalization." Pp. 277-298 in Rethinking Development Economics. London: Anthem Press.

LEWIS, ARTHUR W. 1954.

"Economic Development with Unlimited Supply of Labour." The Manchester School 22:139-191.

MCKINNON, RONALD I. 1973. Money and capital in economic development. Washington DC: Brookings Institution Press.

MENZEL, ULRICH. 1993. " 40 Jahre Entwicklungsstrategie $=40$ Jahre Wachstumsstrategie." Pp. 131- 155 in Handbuch der Dritten Welt. Grundprobleme, Theorien, Strategien. Bonn: Verlag J. H. W. Dietz.

MILONAKIS, DIMITRIS.

2006. "Pioneers of Economic History." Pp. 269-292 in The new development economics. After the Washington Consensus.

New Delhi; London: Tulika Books \& Zed Books.

MORAN, THEODORE H. 1999 Foreign Direct Investment and Development: The New Policy Agenda for Developing Countries and Economies in Transition.

Washington DC: Institute for International Economics.

NGUGI, JOEL M. 2006. The World Bank and the Ideology of Reform in International Economic Development Discourse. http://law.bepress.com/ expresso/eps/1377. 
NORTH, DOUGLASS C. 1990. Institutions, Institutional Change and Economic Performance.

Cambridge: Cambridge

University Press.

NURKSE, RAGNAR. 1961 Problems of capital formation in underdeveloped countries. New York: Oxford University Press.

OCAMPO, JOSÉ ANTONIO, JAN KREGEL, and STEPHANY GRIFFITH-JONES, eds. 2007. International Finance and Development. London, New York: Zed Books.

OCAMPO, JOSÉ ANTONIO, and MARÍA ANGELA PARRA. 2007.

"Explaining the Dual Divergence: The Role of External Shocks and Specialization Patterns." Pp. 98-127 in Growth Divergences: Explaining Differences

in Economic Performance.

Hyderabad, London and Penang:

Orient Longman, Zed Books and

Third World Network.

POTTINGER, LORI. 2007.

Raising the bar on big dams. Making the case for dam policy reform at the European Investment Bank. Prague: CEE Bankwatch Network, International Rivers Network http://bankwatch.org/ documents/raising_the_bar.pdf.

PREBISCH, RAÚL. 1948

Desarollo Económico de América Latina y sus Principales Problemas. Santiago: CEPAL.
RASCHKY, PAUL A., and MANIJEH SCHWINDT. 2009. Aid, Natural Disasters and the Samaritan's Dilemma. Washington DC: World Bank http://www-wds.worldbank. org/external/default/ WDSContentServer/IW3P/IB/2009 /06/03/000158349_20090603154059 /Rendered/PDF/WPS4952.pdf.

RODRIGUEZ, FRANCISCO, and DANI RODRIK. 1999. Trade Policy and Economic Growth: A Skeptic's Guide to CrossNational Evidence. Washington DC: National Bureau of Economic Research http://ideas. repec.org/p/nbr/nberwo/7081. html (Accessed February 1, 2010).

RODRIK, DANI. 2008. "Industrial development: Some stylized facts and policy directions." Pp. 7-28 in Industrial Development for the 21st Century. London, New York: Zed Books.

ROSE, NIKOLAS S. 1999. Powers offreedom: reframing political thought. Cambridge: Cambridge University Press.

ROSENSTEIN-RODAN,

PAUL N. 1943. "Problems of Industrialisation of Eastern and South-Eastern Europe." The Economic Journal 53:202-211.

ROSTOW, WALT W. 1960. The Stages of Economic Growth: A Non-Communist Manifesto. Cambridge: Cambridge University Press.
SHAW, EDWARD S. 1973.

Financial deepening in economic development. New York: Oxford University Press.

SHIRLEY, MARY, and JOHN NELLIS. 1991. Public Enterprise Reform: The Lessons of Experience. Washington DC: World Bank.

SINGER, HANS W. 1950. "The Distribution of Gains between Investing and Borrowing Countries." The American Economic Review 40:473-485.

STIGLITZ, JOSEPH E. 1998a.

"More Instruments and Broader Goals: Moving Toward the PostWashington Consensus.” vol. 2, WIDER Annual Lecture. Helsinki: UNU-WIDER http://www.wider. unu.edu/publications/annuallectures/en_GB/AL2/ (Accessed January 5, 2010).

STIGLITZ, JOSEPH E. 1998b.

"Towards a New Paradigm for Development.” vol. 9, Raúl Prebisch Lecture. Geneva: UNCTAD.

STIGLITZ, JOSEPH E. 2001.

"An Agenda for the New

Development Economics (Draft)." Cape Town: UNRISD.

TRICARICO, ANTONIO. 2008.

"Which policy coherence for EIB lending in developing countries?" Berlin.

WADE, ROBERT. 1990. Governing the market: economic theory and the role of government in East Asian industrialization. New Jersey: Princeton University Press.
WEED. 2008. Coherence for development? Development check of the financing activities of the European Investment Bank. Berlin: WEED e.V. (World Economy, Ecology and Development) http://www.counterbalanceeib.org/component/option,com datsogallery/Itemid,86/file,weed_ coherence_berlin08.pdf/ func, download/.

WILKS, ALEX. 2010. Corporate welfare and development deceptions. Why the European Investment Bank is failing to deliver outside the EU. Brussels: Counter Balance http://www.counterbalanceeib.org/component/option,com_ datsogallery/Itemid,98/ file,SReport-EN-web.pdf/ func, download/.

WILLIAMSON, JOHN. 1990. "What Washington Means by Policy Reform." Chapter 2 in Latin American Adjustment: How Much Has Happened? Washington DC: Peterson Institute for International Economics.

WILLIAMSON, OLIVER E. 1985. Economic Institutions of Capitalism. New York, London: Free Press.

WORLD BANK. 2000.

Helping countries combat corruption: progress at the World Bank since 1997. Washington DC: World Bank.

WORLD BANK. 2001. World Development Report 2002: Building Institutions for Markets. Washington DC: Oxford University Press for the World Bank. 
WORLD BANK. 1997. World Development Report The state in a changing world. Washington DC: Oxford University Press for the World Bank.

WRIGHT, CHRISTOPHER. 2007. European Investment Bank: Promoting sustainable development, "Where appropriate". Prague: CEE Bankwatch Network http://bankwatch.org/documents/ EIB_where_appropriate.pdf.

\section{ElB documents}

Development Impact Assessment Framework of Investment Facility Projects. http://www. eib.org/attachments/thematic/ eib_diaf_en.pdf

Economic report on partner countries 2005. A report by the Development Economics Advisory Service (DEAS). http://www. eib.org/attachments/strategies/ deas_report_2005_en.pdf

Economic report on partner countries 2006. A report by the Development Economics Advisory Service (DEAS). http://www. eib.org/attachments/strategies/ deas_report_2006_en.pdf

Economic report on partner countries 2007. A report by the Development Economics Advisory Service (DEAS). http://www. eib.org/attachments/strategies/ deas_report_2007_en.pdf
Economic report on partner countries 2008. A report by the Development Economics Advisory Service (DEAS). http://www. eib.org/attachments/strategies/ deas_report_2008_en.pdf

EIB financing for mining projects. http://www.eib.org/projects/ news/eib-financing-for-miningprojects.htm

EIB Group's 1999 Annual Report. http://www.eib.org/attachments/ general/reports/ar1999en.pdf

EIB Group's 2001 Annual Report. http://www.eib.org/attachments/ general/reports/ar2001en.pdf

EIB Group's 2005 Annual Report. http://www.eib.org/attachments/ general/reports/ar2005en.pdf

EIB Group's 2007 Annual Report. http://www.eib.org/attachments/ general/reports/ar2007en.pdf

EIB signs Corporate Governance Approach Statement. http://www. eib.org/about/press/2007/2007-109eib-signs-corporate-governanceapproach-statement.htm

EIB support for the Extractive Industry Transparency Initiative. http://www.eib.org/projects/ news/eib-support-for-theextractive-industry-transparencyinitiative.htm

European Investment Bank activities in Microfinance in Africa, the Caribbean and the Pacific. http://www.eib.europa. eu/attachments/strategies/ microfinance_2008_en.pdf
European Investment Bank financing in Asia and Latin America. http://www.eib.org/ projects/publications/europeaninvestment-bank-financing-inasia-and-latin-america.htm

Euro-Mediterranean trade relations are healthy and growing. http://ec.europa.eu/trade/ creating-opportunities/bilateralrelations/regions/euromed/ index_en.htm

Investment Facility Annual Report 2003. http://www.eib. org/attachments/country/ if_annual_report_2003_en.pdf

Statement on Corporate Social Responsibility. http://www.eib. org/attachments/strategies/ statement_csr_en.pdf

The EIB - a development partner and the Millennium Development Goals. http://www.eib.org/about/ news/the-eib-a-developmentpartner-and-the-millenniumdevelopment-goals.htm

Veracel Pulp Mill Project, Brazil. http://www.eib.europa.eu/ projects/news/veracel-pulp-millproject,-brazil.htm?lang=-en

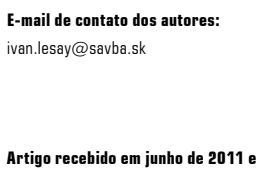


